\title{
Effects of flow regulation and river channelization on sandbar bird nesting availability at the Lower Vistula River
}

\author{
Michał Habel \\ Institute of Geography, Department of Revitalization of Waterways, \\ Kazimierz Wielki University in Bydgoszcz, \\ Plac Kościeleckich 8, 85-033 Bydgoszcz, Poland, \\ e-mail: hydro.habel@ukw.edu.pl
}

Received: 4 March 2018 / Accepted: 25 June 2018

\begin{abstract}
The Vistula transports large volumes of river load, with notable prevalence of bed load. Considerable flow irregularity over the course of a year creates favourable conditions for the formation of sand islands (bars) at the mid and lower river reach. As the bars remain emerged for long periods of time, they constitute resting and nesting grounds for water avifauna, particularly species of the Charadriidae and Laridae family. In consequence of regulatory works performed in the 19th century at the lower Vistula reach, the channel has been devoid of natural islands overgrown with riparian forests and the accompanying minor sand bars. In turn I observe a prevalence of low and, as far as morphology is concerned, poorly diversified alternating accumulation forms. Moreover, operation of the dam erected in the 1970s has increased water level fluctuation frequency in the channel below, thus resulting in more frequent inundation of sandbars. This is particularly adverse for water birdlife, whose habitats become flooded during the breeding season. Morphometric research paired with the analysis of hydrological data allowed us to indicate threshold water flow conditions at which sandbars become submerged. Furthermore, efforts were made to determine the number of potentially successful breading seasons in the years 1986-2015. Identifying the dates and the range of flood waves caused by the dam operation made it possible to indicate the number of complete and interrupted breeding cycles on sandbars. Most importantly, the study seeks to answers the question whether the habitat conditions at the regulated lower Vistula reach are sufficient to allow water birdlife to bread.
\end{abstract}

Keywords: Lower Vistula, sand bars, water avifauna, dam impact, water flow fluctuation, channel regulation.

\section{Introduction}

Every human intervention in river channel processes, particularly when damming is involved, exerts adverse effect on the continuity of fluvial phenomena (Habel et al., 2017). Hydrological regime of rivers constitutes an especially significant factor determining the condition of ecosystems (Allan, 1995; Lenhart et al., 2013). Islands and sand bars on rivers serve as natural resting places and safe nesting grounds for waterfowl (Smith \& Renken, 1991; Sidle \& Kirsch, 1993). River bars can be regarded as a transition zone between water and land, since they become submerged only during high water levels (Tracy-Smith et al.,
2012). Junk et al. (1989) refers to this area as the aquatic/ terrestrial transition zone (ATTZ).

Formation of a large number of shallows in the river channel is considered a natural occurrence within reaches overloaded with river debris. The Vistula river transports $700,000 \mathrm{~m}^{3}$ of sand material per annum (Babiński, 1992a). Such amount ensures good conditions for the formation of sandbars. As a result, various types of bars, i.e. channel mesoforms, tend to form over the entire course of the Vistula river (along with microforms, such as ripplemarks and dunes). At the mid-section of the Vistula and within its unregulated reach the said forms include mostly midchannel bars, near-island bars and braid bars. The regu- 
lated reach sees the prevalence of alternate-diagonal bars (Fig. 1). These bar types differ in terms of their morphological character, as well as surface and edges stability, which translates into diverse habitat conditions for water fauna and flora. The Vistula sand bars are commonly believed to serve as potential breeding places for water avifauna, which has been confirmed in a number of research works, including Bukaciński et al. (2011, 2013), Kot et al. (2009), Keller et al. (1998), Chyralecki et al. (1995) and Wesołowski et al. (1984). As far as the lower Vistula reach is concerned, and more specifically the regulated section below the dam, there are no documented bird breeding successes. Thus, a question arises whether such studies have not been conducted or perhaps habitat conditions at this river section, and within the active river channel in particular, are insufficient for birds. Williams and Wolman (1984), Walker (1985) and Andrews (1986) argue that dam operation tends to cause geomorphological changes arising from a deficit in river load transport, as well as changes in river regime. Research results demonstrate that the construction of the single dam in 1968, which was meant to be one of 9 structures in the planned and abandoned cascade project, has interfered with natural water flow and river load transport (Babiński, 1992a; Habel, 2013). Frequent water level fluctuation is particularly notable within the reach stretching from the Włocławek dam to the river mouth at the Bay of Gdańsk, which is mostly a result of maintenance works conducted at the dam, intervention water discharges for the purpose of in-land navigation and, to a lesser degree, the dam operation itself (Habel, 2013). Before the first half of the 19th century, i.e. up until regulation works were performed, the lower Vistula channel had had a braided-anastomosing character (Babiński, 1992a). Certain river sec- tion, at least to some extent, have to this day retained their unregulated character, i.e. reaches between the town of Annapol and the Kamienna river mouth, between the mouth of the Wieprza river and the Pilica mouth, and between the Pilica mouth and the Wilanówka mouth (Fig. 1). In consequence of regulation works, the lower Vistula river channel is at present devoid of islands with riparian forest and the accompanying disarray of minor sandbars, in turn featuring low and monotonous alternate bars (Fig. 1). Moreover, the fully regulated reach is subject to strong pression of the Włocławek dam operation, which translates into a growing zone lacking in bed load transport.

This paper aims to determine the impact of hydrological and geomorphological limitations occurring at the regulated Vistula reach on habitat conditions considered essential to the breeding of water avifauna. Specific objectives include determining threshold water flow value, at which sandbars, i.e. areas on the verge of water and land or ATTZ according to Junk et al. (1989), become submerged. Furthermore, it is of importance to indicate the frequency and exact dates of sandbar inundation (flood pulse) caused by the Włocławek dam operation. This calls for establishing, using geodetic methods, absolute and relative heights of sandbars, as well as detailed analysis of hydrological data based on statistical and graphical data pertaining to the past thirty years.

\section{Study area}

The work presents detailed results of studies performed on the Vistula river reach regulated in the 19th century, which spans from the vicinity of Solec Kujawski (Rkm 763.0; ki-
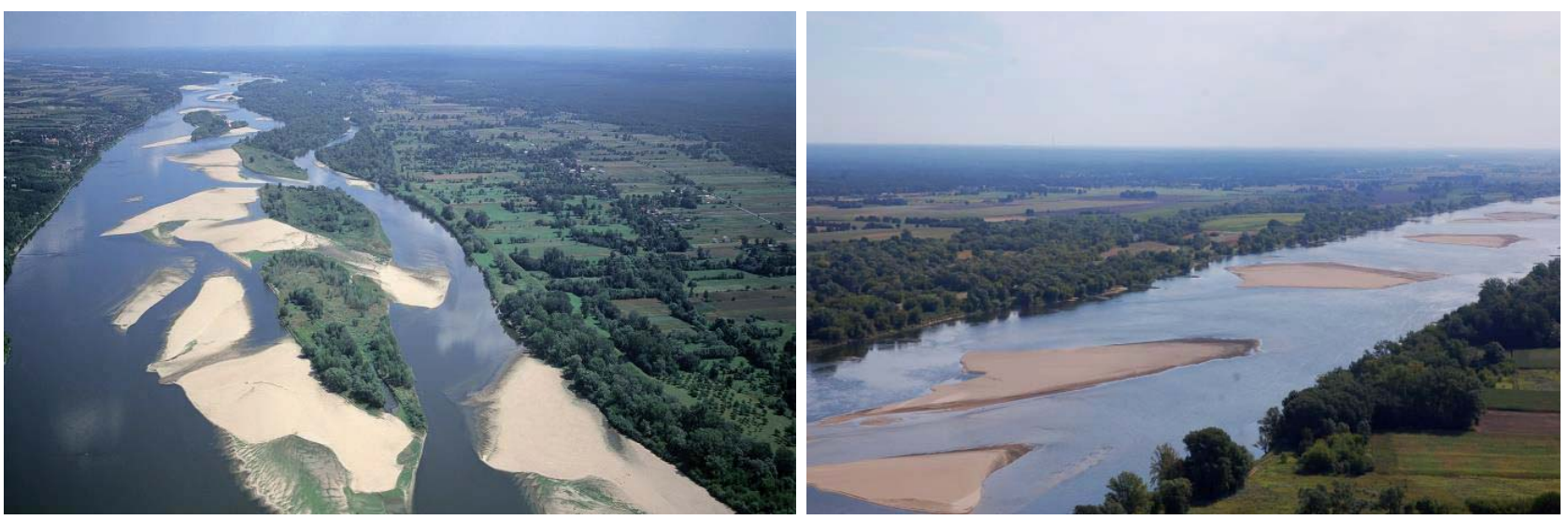

Figure 1. The mid-section of the Vistula river in the vicinity of the Pilica river mouth (left) and a regulated lower Vistula reach at the Brda river mouth below Fordon (right). Fragment featuring mid-channel, near-island and lateral sandbars. The photographs was taken during low water levels in 2015. Photograph to the right was provided by the Sustainable Development Foundation in Warsaw (Lenart W., Magnuszewski A. \& Nowicki W. (eds), 2014) 
lometers calculated from the mouth of the Przemsza River in Upper Silesia - start of the navigable Vistula) to the town of Bydgoszcz-Fordon (Rkm 774.9) (Fig. 2). The Vistula reach in question is linear, with a constant width set out by hydrotechnical structures, and features a sinusoidal course (Fig. 1). The analysis of aerial photographs taken in August 2015 shows that this over $250 \mathrm{~km}$-long reach accommodates up to 200 sandbars of alternate-diagonal type. Regulation works performed in the mid-19th century were meant to improve in-land water navigation conditions and limit some of the ice-related phenomena. These regulation-oriented efforts failed to eliminated sandbars from the channel and, by extension, reduce the risk of ice jam occurrences (Babiński, 1992a). However, the works did improve depth for navigation, as the surface height of bars dropped by approx. $0.5 \mathrm{~m}$ compared to those found at unregulated river reaches (Babiński, 1992b).

Hydrological regime of the lower Vistula is mostly defined by water flows prevailing in the mid-section of the river as well as the inflow of water from the Narew river. High water levels tend to occur in March and April, less frequently in summer (Table 1). The former are related to early-spring melt-water runoff, the latter - usually short- term - result from summer rainfalls. In both cases flood waves are formed with a relative height of 3-5 m, maximum of up to $7 \mathrm{~m}$. Mean annual water flow in the Vistula in Torun amounts to approx. $1008 \mathrm{~m}^{3} / \mathrm{s}$, whereas in Tczew it is approx. $1090 \mathrm{~m}^{3} / \mathrm{s}$ (Bąk \& Kubiak-Wójcicka, 2017). For detailed analysis of hydrological conditions we elected to use data from the gauging station in Fordon, which is located in the vicinity of the Brda river mouth at kilometer 774.9. Zero on the staff gauge is at $24.74 \mathrm{~m}$ a.s.1. In average and wet years, water levels drop below mean low water stages 90 days a year. In dry years, on the other hand, this occurs on 200 days per annum. The lowest water levels are recorded in August, September and November (Table 1). Mean water levels at the Fordon water gauge range from $236 \mathrm{~cm}\left(\mathrm{Q}=982 \mathrm{~m}^{3} / \mathrm{s}\right)$ in summer to $298 \mathrm{~cm}$ in winter - on average $267 \mathrm{~cm}$.

The construction of the Włocławek dam in 1968 has affected the hydrological regime of the river within an over $200 \mathrm{~km}$-long reach below the structure. Despite the amendment introduced to the Water Law Act (Ustawa Prawo wodne, 2001), daily water level fluctuation caused by the dam operation is notable to this day. Hourly water level fluctuation is largely a result of controlled mini

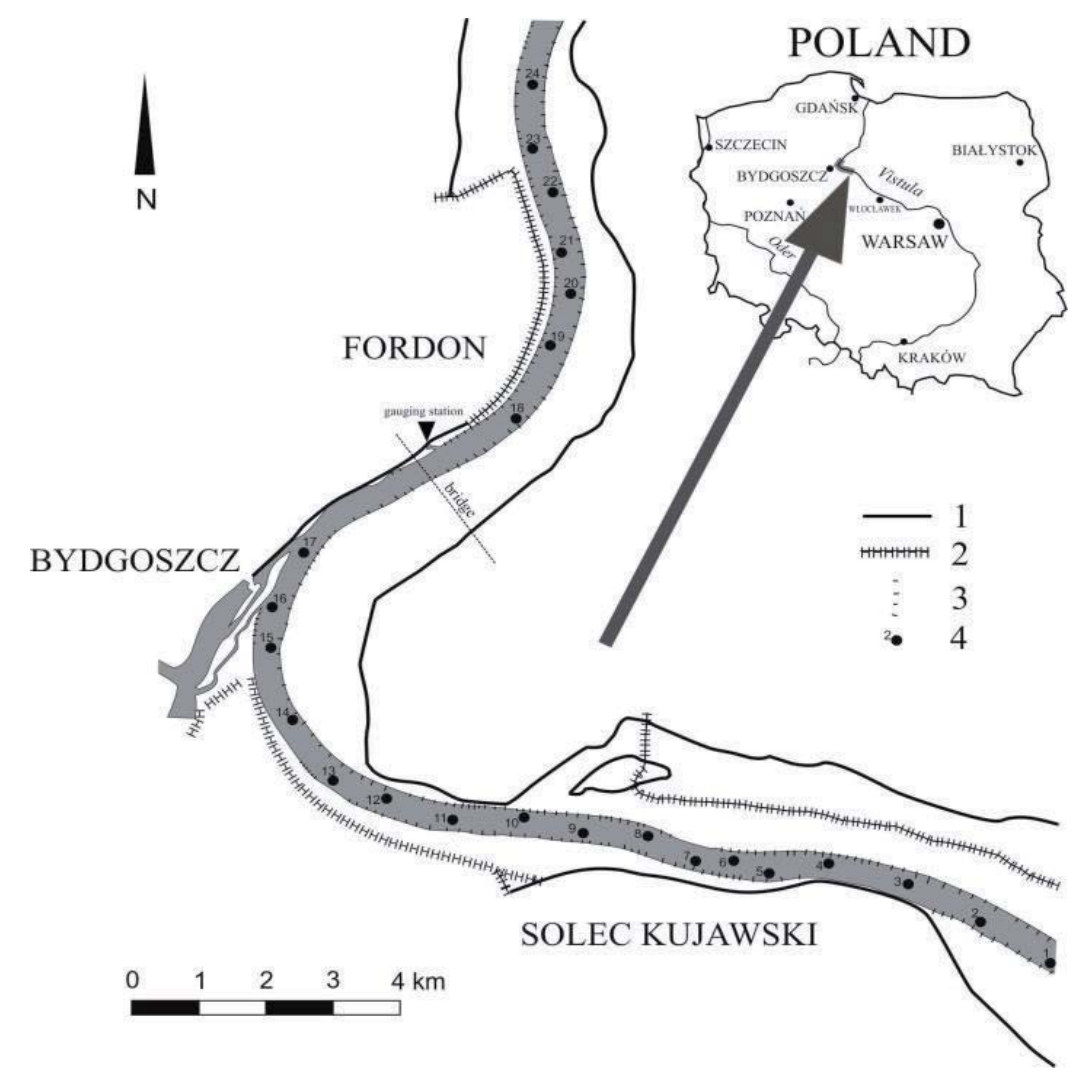

Figure 2. Location of the Lower Vistula river reach under study. Explanation: 1 - borderline for flood water, 2 - embankment, 3 river groynes/dikes, 4 - investigated sandbars 
floods. Artificial floods are released during regular maintenance works as well as for the purpose of increasing depth for navigation - a need arising several times per navigation season. Artificial flood waves occur when water flow through the dam is completely shut off for several hours and then is subsequently resumed. This occurrence and its consequences have been discussed in detail in the works of Habel (2013). Each artificial flood wave is induced in accordance with the "Instruction of Water Management at the Włocławek Dam" (2006). The document states that water discharges at the Włocławek dam are to be performed when water flow in the Vistula drops below $800 \mathrm{~m}^{3} / \mathrm{s}$. During such water discharge, water flow through the Włocławek hydropower plant reaches the maximum of $1170 \mathrm{~m}^{3} / \mathrm{s}$, and this may last up to 12 hours. The value $\left(1170 \mathrm{~m}^{3} / \mathrm{s}\right)$ exceeds the mean water flow estimated for the study reach of $1008-1090 \mathrm{~m}^{3} / \mathrm{s}$. This means that each controlled flood wave inundates sandbars for at least several hours. The volume of discharged water amounts to approx. 30 million $\mathrm{m}^{3}$ (7.4\% of total volume of Włocławek reservoir or $56.6 \%$ of its useful volume).

The Vistula valley constitutes a bird sanctuary of both state and European rank. During the breeding season birds tend to use it to breed and look after hatchlings, later in the autumn and spring season it serves as an important migration route and a place of rest, and later it constitutes an overwinter area. The study channel section along with the flood plain area were included in the Natura 2000 protected area when Poland accessed the European Union, forming the Lower Vistula Valley (area code: PLB040003), a special area of Solecka Vistula valley (area code: PLH040003) and fragments of the ecological corridor of international importance here, n. "Lower Vistula Valley" (corridor code: GKPn-10A) and the corridor of the national network of ecological corridors "Puszcza Bydgoska" (corridor code: GKPnC-14). The area in question features breading and migrating populations of species included in Annex I of the Bird Directive - 28 bird species, of which 9 are found on the Polish Red List. The most important species representing avifauna that may potentially breed on the Mid and Lower Vistula sandbars include birds of the family Charadriidae and Laridae: Charadrius dubius, Charadrius hiaticul, Actitis hypoleucos, Chroicocephalus ridibundus, Larus cachinnans, Larus melanocephalus, Larus canus, Larus ridibubdus, Sterna hirundo, Sternula albifrons (Bukaciński et al., 2011). One should note that sandbars also serve as feeding and resting ground for other bird species, including Ardea cinerea, Vanellus vanellus, Haliaeetus albicilla, Phalacrocorax carbo.

\section{Materials and methods}

The study involves own measurement data, including the results of observations concerning sandbars dynamics on the lower Vistula, with respect to both its regulated and unregulated reach, commenced by Babiński in the years 1981-1989 (Babiński, 1992b) and continued after the year 2005. Authors' current state of knowledge pertaining to the functioning of the lower Vistula channel environment within the regulated reach allowed us to select a several kilometer-long river fragment for a detailed analysis of

Table 1. Characteristic water levels of the Vistula river in the Fordon profile (river km 774.9) in the years 2003-2012. Hydrological year divided into summer season (coinciding with the breading season of avifauna) and winter season

\begin{tabular}{|c|c|c|c|c|c|c|c|c|c|c|c|c|}
\hline Water stages & XI & XII & $\mathbf{I}$ & II & III & $\begin{array}{c}\text { months } \\
\text { IV }\end{array}$ & $\mathbf{V}$ & VI & VII & VIII & IX & $\mathbf{X}$ \\
\hline $\begin{array}{l}\text { MLWL - } \\
\text { average low } \\
\text { water stage }\end{array}$ & 182 & 181 & 172 & 239 & 205 & 287 & 215 & 193 & 162 & 154 & 152 & 158 \\
\hline $\begin{array}{l}\text { MWL - } \\
\text { average water } \\
\text { stage }\end{array}$ & 231 & 237 & 284 & 307 & 353 & 374 & 292 & 266 & 222 & 230 & 210 & 197 \\
\hline $\begin{array}{l}\text { MHWL - } \\
\text { average high } \\
\text { water stage }\end{array}$ & 306 & 316 & 373 & 433 & 483 & 460 & 387 & 389 & 325 & 347 & 298 & 279 \\
\hline $\begin{array}{l}\text { MWL - } \\
\text { average water } \\
\text { stage }\end{array}$ & \multicolumn{6}{|c|}{ Winter season 298} & \multicolumn{6}{|c|}{$\underline{\text { Summer season } 236}$} \\
\hline $\begin{array}{l}\text { Extreme water } \\
\text { stages obs. }\end{array}$ & \multicolumn{3}{|c|}{$\begin{array}{c}\max .875 \\
\text { March 30-31th, } 1924\end{array}$} & \multicolumn{3}{|c|}{$\begin{array}{c}\text { min. } 121 \\
\text { Dec. 6th, } 1892\end{array}$} & \multicolumn{3}{|c|}{$\begin{array}{c}\max .824 \\
\text { June } 12 \text { th, } 1962\end{array}$} & \multicolumn{3}{|c|}{$\begin{array}{c}\text { min. } 118 \\
\text { Sep. } 11 \text { th, } 2012\end{array}$} \\
\hline
\end{tabular}


hydrological data and morphological measurements. And thus, the section located half way between the extreme points, i.e. the Włocławek Dam and Tczew, was deemed to be representative for the entire study reach. In the period between August 2015 and December 2016, data were collected using geodetic methods to determine the morphometric parameters of 24 sandbars found between river kilometer 760 and 782 (Fig. 1 - left). The following features were measured and calculated for each sandbar: emerged surface area at a specific water level, wetted perimeter of the emerged part, average height measured from the water surface, longitudinal slope measured from the tail to the front of a bar. Two height zones have been identified for each sandbar: a higher, frontal part and a lower, rear part. Measurements of absolute heights required the use of a GNSS Trimble 5800 receiver and a Trimble M2 Series total station. Moreover, the data were supplemented with aerial photographs. Bathymetric maps were prepared based on depth measurements performed with a singlebeam echo sound at high water levels.

Hydrological data in the form of daily water levels and flow values at the Fordon gauging station proved particularly useful when performing detailed assessment of frequency and dates of artificial wave occurrences in the breeding months of water birdlife. The acquired raw data pertaining to the 30 year-long period (1986-2015) were analysed both graphically and statistically, including a matrix diagram for dates and duration of water levels. The data subject to hydrological analysis were provided by the Institute of Meteorology and Water Management in Warsaw - National Research Institute [IMGW-PIB], as well as Regional Water Management Authority in Gdańsk [RZGW in Gdańsk]. Various ship-owners provided data pertaining to the frequency of special cargo transport on the Vistula river, which includes barges produced in Płock at Centromost Sp. z o.o. [Ltd.] shipyard and icebreakers on route from Gdańsk to the Włocławek dam.

The common gull (Larus canus) is the best described representative of avifauna nesting on the Vistula sandbars. Therefore, based on information available in literature, we set out to define conditions suitable for the habitat of Larus canus. The breeding season is assumed to last from April 1 st to September 30th each year. The works of Bukaciński et al. (2015) indicate that eggs are laid typically in the second half of April, with a peak at the beginning of May. Birds migration commences at the turn of September and October, which can be accepted as the end of the breeding season. Furthermore, estimation was made concerning the number of days required for a successful breeding. As indicated by Bukaciński \& Bukacińska (2015), hatching (incubation) of eggs by Larus canus takes from 24 to 31 days, and the hatchlings fledge after 22-33 days. This means that the total amount of time required for the reproduction of these birds (from breeding to fledging) is no less than
46-64 days - given that there are no breaks caused by habitat inundation. Even if I was to assume that birds are capable of moving, for instance over the water surface, after merely half the time needed for fledging, the minimum time required for a successful breeding is still $35-46$ days.

\section{Results and discussion}

Information gathered from an extensive body of literature paired with field survey results indicate that sandbars found at the study reach have lengths of 800 to $1200 \mathrm{~m}$ and an average width of $300 \mathrm{~m}$. Their surface height typically falls within the range of mean low water levels (MLWL) and low water levels (LWL). However, sandbars here are lower than at the unregulated river reach. The difference between their absolute height and the water table depends largely on the sandbar type, which in turn is determined by hydraulic parameters of the channel - hydraulic radius in particular. Mid-channel and near-island sandbars that form in the 700-900 metre-wide section of the middle Vistula channel are approx. $0.5-0.8 \mathrm{~m}$ higher than alternate-diagonal sandbars typically found at the regulated river reach. The morphology of alternate-diagonal sandbars may shift multiple times a year, depending on water levels prevailing at a given time (Babiński, 1992b). Thus, at low water levels the edges of alternate-diagonal bars tend to erode, subsequently forming the so-called linguoid bars. On the other hand, even minor floods and increased water levels lasting merely several hours tend to alter the sandbar surfaces and move them downstream. In general, every increase in flow intensity appears to correspond to a proportional increase in dynamics and vice versa. The rate at which alternatediagonal sandbars move downstream was estimated to 0.4-2.4 m per day (Babiński, 1992a). Nevertheless, there were some instances where the rates considerably deviated from the above-mentioned average values. Going beyond their zone corresponding to a uniform movement of sandbars, it was proved that alternate-diagonal sandbars could reach $6.5 \mathrm{~m}$ for a day. In other words, at a certain stage of channel processes development, related to hydrological regime, the downstream movement of bars and their transformation accelerates considerably. This occurs at the so-called morphological threshold, which in the case of a regulated channel is only one, i.e. when water flows over a sandbar surface or recedes from it. As shown above, inundation of a sandbar - even as short as several hours results in remodelling of its surface.

The analysis of hydrological data and geodetic measurements enabled us to determine the limit value of water flow, at which the emerged parts of sandbars become inundated within the study reach of the Vistula river. Geodetic measurements performed as part of the study show that when water surface is at an elevation of $29.25 \mathrm{~m}$ a.s.l. at 
the Fordon gauging station, with water stage of $240 \mathrm{~cm}$ and flow of approx. $985 \mathrm{~m}^{3} / \mathrm{s}$, the highest frontal parts of sandbars remain emerged. For a sandbar to emerge entirely, water stage must drop by another $50 \mathrm{~cm}$. As it turns out, the indicated limit value of $240 \mathrm{~cm}$ corresponds to mean annual water level in the Vistula in the period from May to October - $236 \mathrm{~cm}$ (calculated for the years 2003-2012). At the unregulated reach of the Lower and Middle Vistula, sandbars can emerge at water flows of approx. $1050 \mathrm{~m}^{3} / \mathrm{s}$.

In addition, it was found that during controlled minor floods caused by the Włocławek dam operation, daily water levels in the direct vicinity of the dam may increase by up to $200 \mathrm{~cm}$, up to $100 \mathrm{~cm}$ at a distance of $100 \mathrm{~km}$ further downstream, and up to $60 \mathrm{~cm} 200 \mathrm{~km}$ below the structure (Habel, 2013; Habel \& Babiński, 2015). When comparing the hydrological regime of the Vistula river at the reach unaffected by the operation of the Włocławek dam $(100 \mathrm{~km}$ upstream of the Wloclawek Reservoir) with the river reach below the dam against the graph illustrating the course of daily water levels, we can clearly observe certain differences (Fig. 3). The hydrograph for the Fordon gauging station indicates the occurrence of controlled minor floods (peaks of approx. $100 \mathrm{~cm}$ ). Data concerning the course of water levels in the period from September 2002 to the beginning of 2016 show that controlled water discharges at the Wloclawek Reservoir were performed over 40 times. Since 2002 water discharges are carried out regularly in summer to accommodate transport of barges produced by Centromost Sp. z o.o. shipyard in Płock, as well as during maintenance works at the lower station of the dam.

The analysis of daily water levels in the Vistula river within the period of 30 years (1986-2015) in the context of the indicated breeding season clearly shows the dates of potential breeding successes as far as the birds of the Charadriidae and Laridae family are concerned, and Larus canus in particular. In 2010 water levels did not drop below $240 \mathrm{~cm}$, which made it impossible for birdlife to use sandbars as their nesting grounds. In other years sandbars remained emerged for a minimum of 7 days in 2013, and a maximum of 125 days in 1993, with an average of 56 days (Table 2). There appears to be a tendency towards the reduction of total time sandbars remain emerged at the study reach during the breeding season. Within the period of 1986-1995 sandbars were exposed for an average of 67 days a year, but in 1996-2005 it was only 48 days. In the last decade (2006-2015) the average exposure time was 52 days. In the breeding season, the largest number of days with sandbar exposition occurred in September (35.59\%), August (31.66\%) and July (18.15\%). May, on the other hand, demonstrated the smallest number of such days $(0.78 \%)$. However, in order to determine the chances for birdlife reproduction and possible breeding success it is necessary to indicate whether there were any 34-day cycles of sandbar exposition uninterrupted with floods (natural or artificial). It was established that conditions that would meet the minimum criteria required by birdlife occurred only in 14 years, i.e. in 1986, 1989, 1990-1995, 2000, 2003, 2006, 2008, 2009 and 2011. Moreover, the year 1990 and 2009 featured two periods conducive to bird breeding, whereas in 1993 sandbars remained emerged for 83 days in succession, which may have potentially resulted in two breeding successes (Table 2). The discussed phenomenon can be traced on the matrix diagram presented below (Fig. 4). Periods featuring favourable conditions oc-

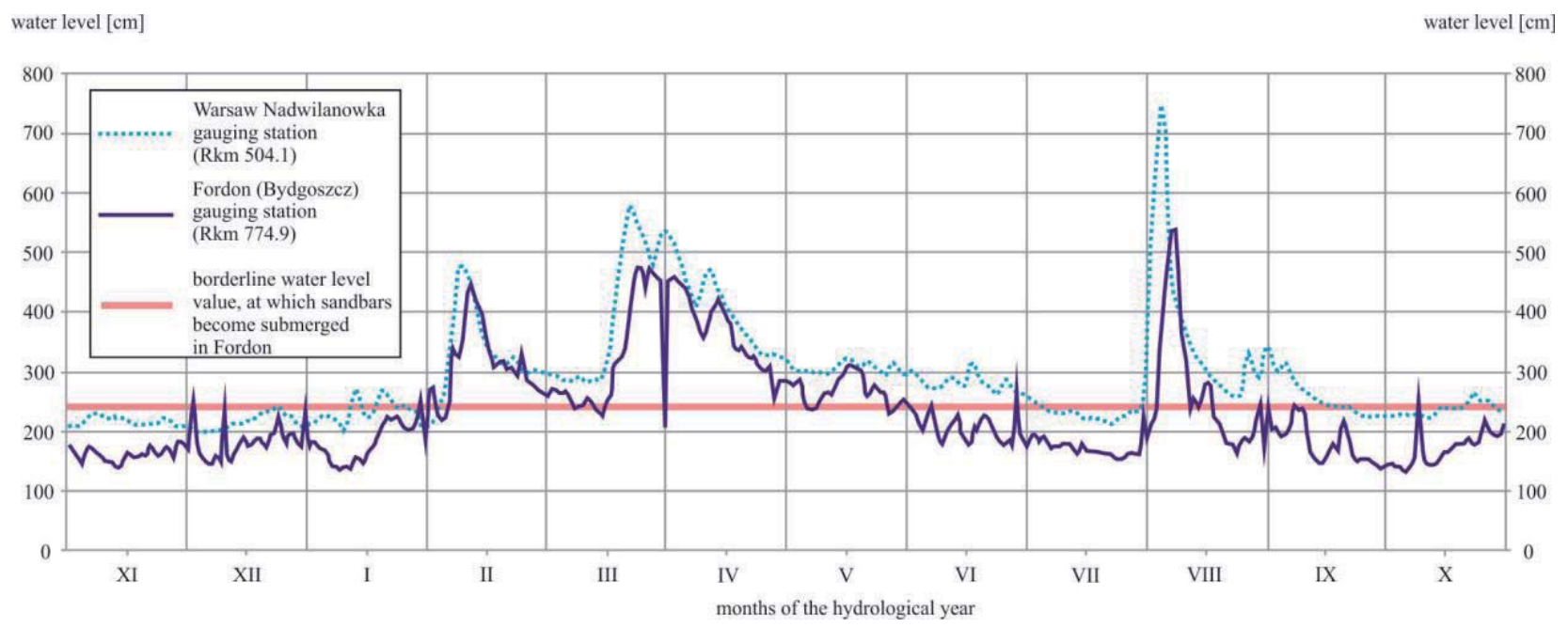

Figure 3. Comparison of water stage graphs (hydrographs) corresponding to two gauging stations on the Vistula river: gauging station in Warsaw, at river km 504.1 (approx. $170 \mathrm{~km}$ above the dam) and in Fordon, at river km 774.9 (100 km downstream of the Włocławek dam) in the hydrological year of 2004 
Table 2. Number of days and dates with water levels below $240 \mathrm{~cm}$ on the lower Vistula river. The data represent exclusively months that correspond with the breeding season of water birdlife. Prepared based on daily water level values at the Fordon gauging station. Data provided by IMGW-PIB and RZGW in Gdańsk

\begin{tabular}{|c|c|c|c|c|c|c|c|c|c|}
\hline \multirow[t]{2}{*}{ Years } & \multicolumn{6}{|c|}{$\begin{array}{l}\text { Duration (in days) of subsequent uninterrupted periods } \\
\text { in a given month }\end{array}$} & \multirow{2}{*}{\begin{tabular}{|c|}
$\begin{array}{c}\text { Duration (in days) } \\
\text { of subsequent } \\
\text { uninterrupted periods } \\
\text { in the breeding season }\end{array}$ \\
IV - IX \\
\end{tabular}} & \multirow[t]{2}{*}{$\begin{array}{l}\text { Total time } \\
\text { of sandbar } \\
\text { exposition }\end{array}$} & \multirow{2}{*}{$\begin{array}{r}\text { Number of } \\
\text { potential } \\
\text { breeding } \\
\text { successes }\end{array}$} \\
\hline & IV & $\mathbf{V}$ & VI & VII & VIII & IX & & & \\
\hline 2015 & 0 & 0 & 0 & $4 ; 2$ & $8 ; 2$ & 30 & $4 ; 2 ; 8 ; 2 ; 30$ & 46 & 0 \\
\hline 2014 & 18 & 0 & 0 & 0 & 2 & 19 & $18 ; 2 ; 19$ & 39 & 0 \\
\hline 2013 & $5 ; 2$ & 0 & 0 & 0 & 0 & 0 & $5 ; 2$ & 7 & 0 \\
\hline 2012 & 4 & 0 & 0 & $3 ; 5$ & 14 & $9 ; 19$ & $4 ; 3 ; 19 ; 9 ; 19$ & 54 & 0 \\
\hline 2011 & 0 & 0 & 8 & 31 & 5 & 2 & $44 ; 2$ & 46 & 1 \\
\hline 2010 & 0 & 0 & 0 & 0 & 0 & 0 & 0 & 0 & 0 \\
\hline 2009 & 0 & 0 & $2 ; 25$ & $21 ; 3$ & 5 & 31 & $2 ; 46 ; 3 ; 36$ & 87 & 2 \\
\hline 2008 & 0 & 0 & 0 & $3 ; 14 ; 7$ & 27 & $8 ; 16$ & $3 ; 14 ; 34 ; 8 ; 16$ & 75 & 1 \\
\hline 2007 & 0 & 0 & $6 ; 9 ; 10$ & $11 ; 2$ & $23 ; 7$ & $25 ; 5$ & $6 ; 9 ; 10 ; 11 ; 2 ; 23 ; 32$ & 93 & 0 \\
\hline 2006 & 2 & 0 & $4 ; 6$ & $3 ; 6 ; 2$ & $5 ; 19$ & 30 & $2 ; 4 ; 9 ; 6 ; 7 ; 49$ & 77 & 1 \\
\hline 2005 & 0 & 0 & 0 & 2 & 31 & $8 ; 4$ & $33 ; 8 ; 4$ & 45 & 0 \\
\hline 2004 & 0 & 0 & $3 ; 21 ; 2$ & $4 ; 21 ; 2$ & 31 & $1 ; 11$ & $3 ; 21 ; 2 ; 3 ; 4 ; 21 ; 33 ; 1 ; 11$ & 73 & 0 \\
\hline 2003 & 13 & 0 & 0 & $2 ; 22$ & $10 ; 20$ & 30 & $13 ; 2 ; 32 ; 10 ; 50$ & 107 & 1 \\
\hline 2002 & 0 & 0 & 19 & 4 & 22 & 31 & $19 ; 26 ; 31$ & 76 & 0 \\
\hline 2001 & 8 & 0 & 0 & 6 & $7 ; 17$ & 0 & $8 ; 13 ; 17$ & 38 & 0 \\
\hline 2000 & 0 & 0 & 0 & $3 ; 20$ & 22 & $1 ; 3$ & $3 ; 42 ; 1 ; 3$ & 49 & 1 \\
\hline 1999 & 0 & 0 & 0 & 0 & 0 & $8 ; 1 ; 9$ & $8 ; 1 ; 9$ & 18 & 0 \\
\hline 1998 & 0 & 0 & 0 & 0 & 0 & 12 & 12 & 12 & 0 \\
\hline 1997 & 7 & 0 & 2 & 0 & 6 & 0 & $7 ; 2 ; 6$ & 15 & 0 \\
\hline 1996 & $7 ; 10$ & 0 & 0 & $2 ; 6 ; 2$ & $8 ; 2 ; 14$ & 0 & $7 ; 10 ; 2 ; 6 ; 2 ; 8 ; 2 ; 14$ & 51 & 0 \\
\hline 1995 & 0 & 0 & 0 & 2 & 14 & 30 & $2 ; 44$ & 46 & 1 \\
\hline 1994 & 0 & 0 & 0 & 1 & 31 & 30 & 62 & 62 & 1 \\
\hline 1993 & $4 ; 13$ & 0 & 16 & 30 & 31 & $4 ; 25$ & $4 ; 13 ; 83 ; 25$ & 125 & 1 or 2 \\
\hline 1992 & 0 & 0 & 10 & $6 ; 7 ; 5 ; 2$ & 31 & 30 & $16 ; 7 ; 5 ; 2 ; 61$ & 91 & 1 \\
\hline 1991 & 0 & 0 & 0 & 1 & 31 & $5 ; 9$ & $37 ; 9$ & 46 & 1 \\
\hline 1990 & 0 & $11 ; 2$ & 16 & $2 ; 26$ & $16 ; 5 ; 6$ & 30 & $11 ; 2 ; 18 ; 42 ; 5 ; 36$ & 114 & 2 \\
\hline 1989 & 0 & 0 & 0 & 0 & $7 ; 10$ & 30 & $7 ; 40$ & 47 & 1 \\
\hline 1988 & 0 & 0 & 5 & 0 & 2 & $24 ; 5$ & $5 ; 26 ; 5$ & 36 & 0 \\
\hline 1987 & 0 & 0 & 0 & 0 & 22 & 25 & $22 ; 25$ & 47 & 0 \\
\hline 1986 & 0 & 0 & 0 & 4 & 31 & 30 & $4 ; 61$ & 65 & 1 \\
\hline $\begin{array}{r}1986 \\
-2015\end{array}$ & $5.6 \%$ & $0.8 \%$ & $8.2 \%$ & $18.15 \%$ & $31.66 \%$ & $35.59 \%$ & $100 \%$ & & \\
\hline
\end{tabular}


curred eleven times at the turn of August and September, four times at the turn of July and August and two times at the turn of June and July (Fig. 4).
One should note that almost every year from 1986 to 1995 featured a potential breeding success (Fig. 4). In the later years, up to this moment (1996-2015), conditions

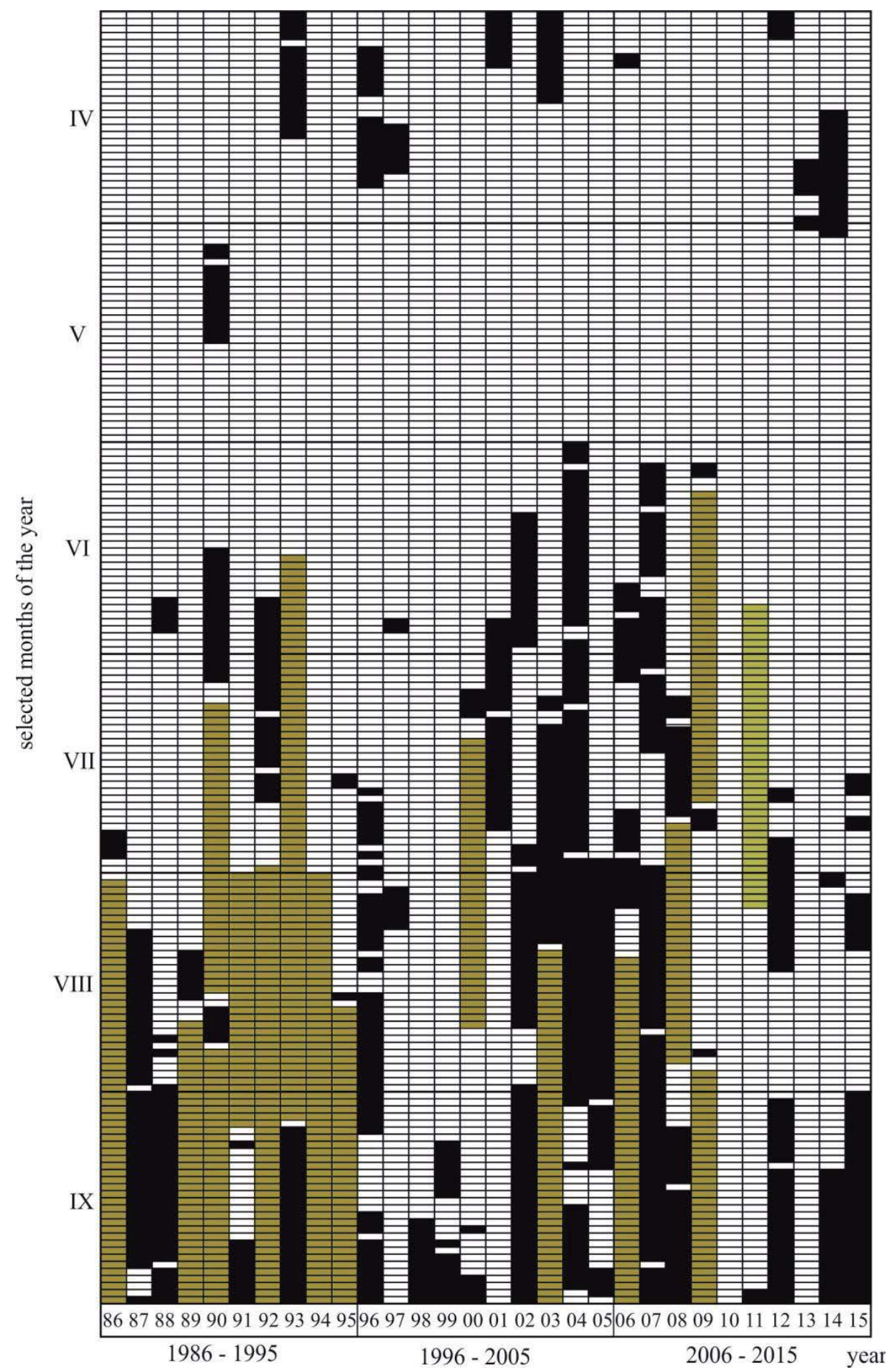

Figure 4. Matrix diagram of daily water levels on the lower Vistula measured at the gauging station in Fordon. Dates with water levels below $240 \mathrm{~cm}$ are marked in black and yelow. Yelow rectangles indicate dates with a potential breeding success of birds from the family Charadriidae and Laridae, Larus canus in particular 
in this respect deteriorated considerably, and a breeding success occurs on average once every three years. The matrix diagram of daily water levels (Fig. 4) indicates the occurrence dates and duration of periods with water levels exceeding the treshold value at which the highest parts of sandbars become submerged. The diagram also shows that after the year 1996 there has been an increase in the occurrence frequency of short, one-day flood episods, as a result of which sandbars become inundated with a 30-100 $\mathrm{cm}$ layer of water. These changes can be attributed to the intervention mode of operation pursued at the dam, which involves performing water discharges for the purpose of navigation. A conclusion can be drawn that had it not been for the artificial flood waves, breeding success in the years 1996-2015 would have occurred not 7 but 13 times, which gives nearly one success per year, and not once every three years. A potential breeding success was interrupted, for instance, in June and July 2004, September 2005, as well as in June, August and September of 2007. In the remaining years the duration of conditions deemed favourable for water birdlife breeding diminished (Fig. 4). Moreover, the water level matrix indicates that in May and June sandbars on the Vistula do not emerge due to increased water levels/ flows typical of spring months. One should note that the beginning of May corresponds to the peak of egg laying, which in this situation on the regulated Vistula reach had never been possible. In June, on the other hand, conditions suitable for bird breeding occurred only in three years (Fig. 4).

The analyses of hydrological data demonstrate that the study Vistula reach currently remains under a considerable human pressure. There is a notable correlation between mean water levels in the breeding season months and total exposition time of sandbars in the entire study period. The increase in water levels results in a reduction of time when sandbars remain emerged (Fig. 5 - strong negative correlation of MWLS to TES, $\mathrm{R}=-0.71)$. Up to the year 2000 there was a correlation between the time of uninterrupted sandbar exposure and the total time of sandbar exposure in the breeding season of a given year (very strong positive correlation of TUSE to TES in the period of 1986-2000, $\mathrm{R}=0.76$ ). After the year 2000 the correlation decreases $(\mathrm{R}=0.48)$, which is a direct result of increased frequency of controlled floods caused by the Włocławek dam operation. For instance, in 2002, 2004 and 2007, in spite of favourable hydrological conditions (low water levels) and considerable total time of sandbar exposition (73-93 days in total), there was no sufficiently long uninterrupted period when sandbars would remain emerged - lack of breeding success (Fig. 5).

\section{Conclusions}

The study demonstrates that hydrological conditions may be of key importance for establishing favourable conditions within the aquatic/terrestrial transition zones (ATTZ). Sandbars occurring within the channel of large rivers may potentially serve as breeding and resting place for water avifauna, hence stability of these forms, both in time and space, is crucial. In the case of the study reach of the Vistula river, regulation works performed in the 19th century imposed considerable geomorphological constraints on water avifauna. As channel width diminished due to the introduction of hydro-engineering structures, former natural islands and small sandbars became replaced by flat,

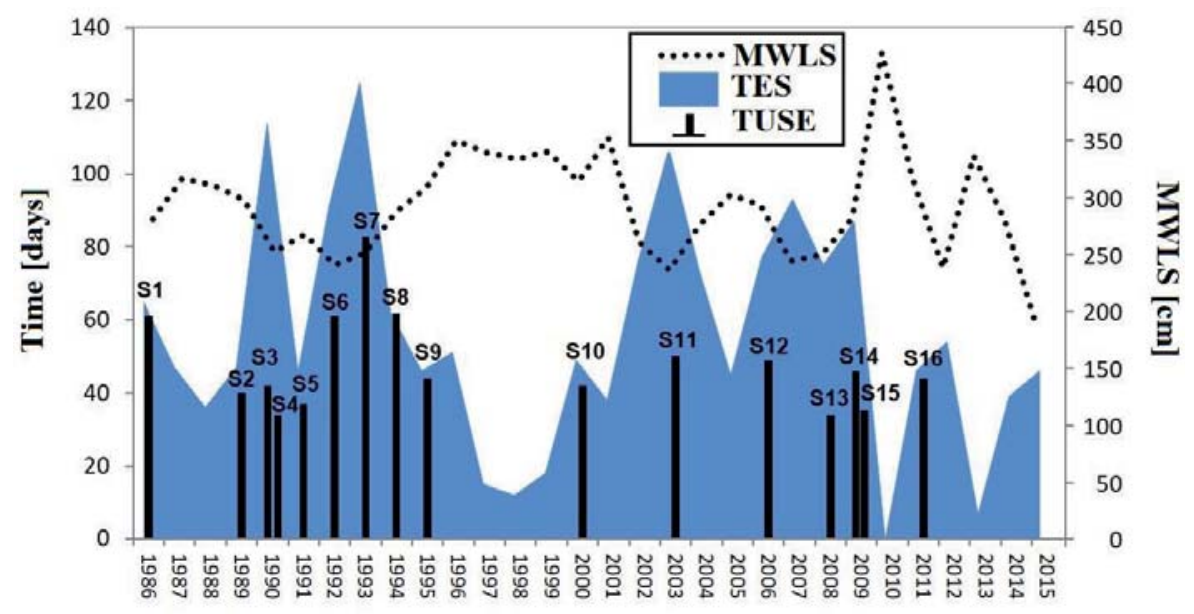

Figure 5. Potential breeding sucesses of water birdlife (S1-S16) on the lower Vistula against the hydrograph of mean water levels in the summer season (MWLS). Total number of days with emerged sandbars during the breeding season (TES) and time of uninterrupted sandbar exposition (TUSE) in days 
lower by $0.5 \mathrm{~m}$ alternate-diagonal bars, which are devoid of natural hiding places for animals (tree trunks, shrubbery, grass patches or reeds). The impact of the Włocławek dam imposes hydrological limitations in the form of frequent changes in water levels within the channel, which in consequence leads to inundation of sandbars. In the conditions of natural hydrological regime that prevail at the mid-section of the Vistula there are typically one or two flood waves per breeding season. However, at the lower Vistula reach there are additional three or even four small artificial flood waves every season and each wave effectively eliminates bird nests and hatchlings found on the sandbars. The analysis was based on the following assumptions:

- breeding seasons lasts from April $1^{\text {st }}$ to September 30th;

- the highest, frontal parts of sandbars remain emerged when water level at the Fordon gauging station oscillates around $240 \mathrm{~cm}$ (water flow - $985 \mathrm{~m}^{3} / \mathrm{s}$ );

- the minimum required time for a breeding success on sandbars amounts to 35 days.

The analysis of hydrological data pertaining to the last 30 years allowed us to draw the following conclusions:

- The hydrological regime of the Vistula enables the birds to breed on sandbars no sooner than in the second half of the breeding season. The largest number of days with exposed sandbars was recorded in the last month of the breeding season, in September (35.59\%), then in August (31.66\%) and July $(18.15 \%)$.

- Only 14 years in the study period featured conditions that met the minimum criteria for successful bird breeding on sandbars. The potential successes occurred eleven times at the turn of August and September, four times at the turn of July and August, and two times at the turn of June and July.

- One can note a tendency towards the reduction of total time sandbars remain emerged at the study reach during the breeding season. In the period of 19861995 the average was 67 days per season, in 19962005 it was 48 days, whereas in the last decade -52 days.

- Artificial floods are reflected in the data recorded at the gauging stations. In the period under study there was a total of 40 artificial flood waves in the summer season and the trend appears to intensify after the year 2000. One should note that in the period of 1986-1995 a potential breeding success was viable in almost every year. After 1996 conditions in this respect have deteriorated, and a breeding success may occur, on average, once every three years.

- If artificial flood waves had been permanently limited within the study reach, in the years 1996-2015 there would have been not 7 but 13 breeding successes, i.e. nearly one per year.
All the above lead us to a conclusion that the regulated Vistula reach does not provide conditions that would sustain the living and breeding of water avifauna. Hydrological regime of the Vistula is considerably altered by the operation of the Włocławek dam, whereas the development of channel forms is restricted by hydro-engineering structures. If the regime of the Włocławek dam operation does not change, habitat conditions for water birdlife - already poor - will further deteriorate. It is essential to implement hydro-engineering projects that would compensate the adverse impact arising from channel regulation. It is also of utmost importance to limit the maintenance-intervention mode of operation currently pursued at the dam in Włocławek.

\section{References}

Allan J.D., 1995, Stream Ecology: Structure and Function of Running Waters. Chapman \& Hall: London, UK.

Andrews E.D., 1986, Downstream effects of Flaming Gorge Reservoir on the Green River, Colorado and Utah. Geol. Soc. Am. Bull. 97(8): 1012-1023.

Babiński Z., 1992a, Współczesne procesy korytowe dolnej Wisły [The present day fluvial processes of the Lower Vistula River]. Polska Akademia Nauk, Instytut Geografii i Przestrzennego Zagospodarowania, Prace Geograficzne 157, Zakład Narodowy imienia Ossolińskich, Wydawnictwo Polskiej Akademii Nauk, Wrocław, Warszawa, Kraków.

Babiński Z., 1992b, Hydromorphological consequences of regulating the lower Vistula, Poland. Regulated Rivers: Research \& Management 7(4): 337-348.

Bąk B. \& Kubiak-Wójcicka K., 2017, Impact of meteorological drought on hydrological drought in Torun (central Poland) in the period of 1971-2015. Journal of Water and Land Development 32: 3-12.

Bukaciński D. \& Bukacińska M., 2015, Kluczowe gatunki ptaków siewkowych na środkowej Wiśle: biologia, ekologia, ochrona i występowanie. T. 1. Mewa siwa, Larus canus. Monografia [Key bird species of the order Charadriiformes along the central Vistula reaches: biology, ecology, protection and distribution. T. 1. Common gull, Larus canus. Monograph]. STOP, Warszawa.

Bukaciński D., Bukacińska M. \& Buczyński A., 2011, Awifauna wodno-błotna środkowej Wisły w okresie lęgowym: wpływ działalności człowieka na rozmieszczenie, liczebność i bogactwo gatunkowe [Water and marsh birds of middle Vistula River during breeding season: the impact of human activities on the distribution, abundance and richness of species]. Studia Ecologiae et Bioethicae 9(2): 67-86.

Bukaciński D., Bukacińska M. \& Buczyński A., 2013, The impact of hydrotechnical facilities on island avifauna: 
a case study of the middle Vistula river. Studia Ecologiae et Bioethica 11: 93-109.

Chylarecki P., Bukaciński D., Dombrowski A. \& Nowicki W., 1995, Awifauna [Avifauna], [in:] E. Gacka-Grzesikiewicz (ed.), Korytarz ekologiczny doliny Wisły. Stan - funkcjonowanie - zagrożenia [Vistula as an Ecological Corridor State - Functioning - Threats]. IUCN Poland, Warszawa: 79-124.

Habel M., 2013, Dynamics of the Vistula River channel deformations downstream of the Włocławek Reservoir. Kazimierz Wielki University Press, Bydgoszcz.

Habel M. \& Babiński Z., 2015, Interwencyjne zasilanie wodami Międzynarodowej Drogi Wodnej E40 ze Zbiornika Włocławskiego na potrzeby transportu wodnego [Intervention water supply for the International Waterway E40 from the Włocławek Reservoir for the needs of water transport]. Logistyka 3: 56.

Habel M., Babiński Z. \& Szatten D., 2017, A comparison of research approaches in estimation of volume changes of a bed load transport along a river course on the example of a large lowland river, [in:] T.E. Simos, Z. Kalogiratou, T. Monovasilis (eds), Proceedings of the International Conference of Computational Methods in Sciences and Engineering 2017 (ICCMSE-2017). AIP Conference Proceedings 1906: 170009(1-4).

Instrukcja gospodarowania wodą na stopniu wodnym we Włocławku [Instruction of Water Management at the Włocławek Dam], 2006. Regionalny Zarząd Gospodarki Wodnej (RZGW) [Regional Warer Management Authority], Warszawa.

Junk, W., Bayley P.B. \& Sparks R.E., 1989, The flood pulse concept in river-floodplain systems, [in:] D.P. Dodge (ed.), Proceedings of the International Large River Symposium (LARS). Canadian Special Publication of Fisheries and Aquatic Sciences 106: 110-127.

Keller M., Chylarecki P. \& Nowicki W., 1998, Przyrodnicze podstawy opracowania optymalnej koncepcji zagospodarowania obszaru doliny Wisły na odcinku od ujścia Pilicy do ujścia Narwi. Inwentaryzacja awifauny lęgowej w 1998 r. dla Instytutu Geografii i Przestrzennego Zagospodarowania PAN [Natural foundations for the development of an optimal management plan for the Vistula Valley between the Pilica River mouth and the Narew River mouth. Inventory of the breeding avifauna in 1998 for the Institute of Geography and Spatial Planning of the Polish Academy of Sciences, Warszawa.
Kot H., Bukaciński D., Keller K., Dombrowski A., Rowiński P. \& Błędowski W., 2009, Inwentaryzacja ptaków w granicach Obszaru Specjalnej Ochrony Natura 2000 Dolina Środkowej Wisły PLB 140004. Raport dla Regionalnej Dyrekcji Ochrony Środowiska (RDOŚ) [Inventory of birds within the Special Protection Area „Dolina Środkowej Wisły” (Central Vistula Valley) Natura 2000 PLB 140004, Report for RDOŚ (Regional Directorate for Environmental Protection), Warszawa.

Lenart W., Magnuszewski A. \& Nowicki W. (eds), 2014, On the Vistula, Album CD. Fundacja na Rzecz Zrównoważonego Rozwoju [Sustainable Development Foundation], Warszawa.

Lenhart Ch.F., Naber J.R., \& Nieber J.L., 2013, Impacts of Hydrologic Change on Sandbar Nesting Availability for Riverine Turtles in Eastern Minnesota, USA. Water 5: 1243-1261.

Sidle J.G. \& Kirsch E.M., 1993, Least tern and piping plover nesting at sand pits in Nebraska. Colonial Waterbirds 16: 139-148.

Smith J.W. \& Renken R.B., 1991, Least tern nesting habitat in Mississippi River Valley adject to Missouri. Journal of Field Ornithology 62(4): 497-504.

Tracy-Smith E., Galat D. \& Jacobson R.B., 2012, Effects of flow dynamics on the aquatic-terrestrial transition zone (ATTZ) of Lower Missouri River sandbars with implications for selected biota. River Research and Applications 28(7): 793-813.

Ustawa z dnia 18 lipca 2001 r. - Prawo wodne, 2001. Dz.U. 2001 nr 115, poz. 1229, Kancelaria Prezesa Rady Ministrów [Water Law Act of 18 July 2001. Journal of Laws 2001, No. 115 item 1229, Chancellery of the Prime Minister], Warszawa.

Walker K.F. 1985, A review of the ecological effects of river regulation in Australia. Hydrobiologia 125: 111-129.

Wesołowski T., Głażewska E., Głażewski L., Nawrocka B., Nawrocki P. \& Okońska K., 1984, Rozmieszczenie i liczebność ptaków siewkowatych, mew i rybitw gniazdujących na wyspach Wisły środkowej [Distribution and numbers of the waders, gulls and terns nesting on islands in the middle course of the Vistula]. Acta Ornithologica 20: 159-185.

Williams G.P. \& Wolman M.G., 1984, Downstream effects of dams on alluvial rivers. Geol. Survey Profes. 1286. 